TEME, г. XLI, бр. 4, октобар - децембар 2017, стр. 951-963

Претходно саопштење

DOI: $10.22190 /$ TEME1704951M

Примљено: 14. 1. 2016.

UDK 316.344.23:64.033

Ревидирана верзија: 15. 11. 2016.

Одобрено за штампу: 15. 11. 2017.

\title{
УЛОГА УПАДЉИВЕ ПОТРОШЫЕ У СОЦИЈАЛНОЈ ИНТЕРАКЦИЈИ И ПЕРЦЕПЦИЈИ
}

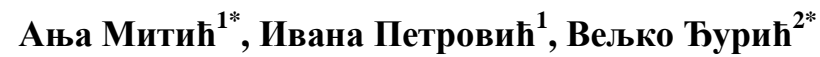 \\ ${ }^{1}$ Универзитет у Београду, Филозофски факултет, Београд, Србија \\ ${ }^{2}$ Факултет за правне и пословне студије др Лазар Вркатић, Нови Сад, \\ Србија \\ *anjamitich@gmail.com
}

\section{Апстракт}

Упадљива потрошња означава куповину и нагомилавање луксузних производа са намером да се истакне завидан друштвени статус. Посматрањем понашања младих у свету можемо уочити доминантно изражавање друштвеног статуса кроз показивање луксузних брендираних производа. Предмет овог рада јесте испитивање утицаја упадљиве потрошње на перцепцију и ставове младих у Новом Саду и Нишу. У раду су наведени резултати емпиријског истраживања експерименталног типа које је имало за циљ да испита улогу овог феномена у социјалној интеракцији и перцепцији младих. Експеримент испитује да ли и како логотипи скупих брендова на одећи утичу на перцепцију особе која је носи. Резултати су потврдили постојање статистички значајних разлика на тринаест од петнаест одабраних карактеристика. Експерименту претходи опсежна неекспериментална студија која је имала за циљ да испита наклоност младих према луксузним производима, посебно одевним предметима. Циљ рада је да укаже на присуство и улогу упадљиве потрошње у савременом контексту, као и да укаже на њен утицај у социјалној интеракцији и перцепцији код младих.

Кључне речи: упадљива потрошња, луксузни производи, социјална перцепција, млади.

\section{ROLE OF CONSPICUOUS CONSUMPTION IN SOCIAL INTERACTION AND PERCEPTION}

\begin{abstract}
The subject of the paper was to examine the effect of conspicuous consumption on the perception and attitudes of young people in Novi Sad and Niš (Serbia). The paper presents the results of the experimental empirical research, aimed to investigate the role of this phenomenon in social interaction and the perception of youth. Experiment has been preceded by extensive non-experimental study with the aim to investigate the attitude of youth towards luxury goods, especially clothes. The experiment tested whether and how logos of expensive brands on the clothes affect the perception of the person wearing them.
\end{abstract}


The results confirmed the existence of significant differences in thirteen of the fifteen selected features. The aim was to indicate the presence and role of conspicuous consumption in the contemporary context, as well as to point out its influence in the social interaction and perception of young people.

Key words: conspicuous consumption, luxury goods, social perception, youth.

\section{УВОД}

Упадљиву потрошњу најчешће дефинишемо као куповину и нагомилавање луксузних производа са намером да истакнемо завидан друштвени статус. Куповина и нагомилавање луксузних производа поседује семантички потенцијал и посредством интегрисаних културних кодова учествује у симболичкој размени између појединаца и група. Са друге стране, постоје еволуциони извори склоности према овом виду симболичке социјалне компетиције. Свићало нам се то или не, одећа коју носимо утиче на то како ће нас други перципирати. Чак и детаљи попут логотипа престижног бренда на мајици могу допринети томе да нас други доживљавају као успешније, компетентније или привлачније. Иако се феноменом упадљиве потрошње научна јавност није дуго бавила, у последњих десетак година ово постаје изузетно атрактивна тема. Упадљива потрошња је толико обележила понашање западне културе и одредила њене класне границе да је постала језгро економских, културолошких, социолошких и психолошких дебата данашњице.

Удружење за истраживање потрошача (Association for Consumer Research) извршило је 1997. године неколико занимљивих истраживања која се тичу упадљиве потрошње и довело овај конструкт у везу са материјализмом, индивидуализмом, колективизмом и свешћу о себи. Објављен чланак носи занимљив наслов „Замисли да поседујеш цео свет, а да то нико не зна?”. Налази ове студије веома су занимљиви. Најпре је утврђено да је у основи материјализма наша жеља да управљамо сликом којом се представљамо другима. Куповина луксузних добара доприноси да одржимо жељену слику о себи, а све је то повезано са упадљивом потрошњом која у овом истраживању има два основна циља: да прикаже успех и да изазове завист других. Посебно је истраживан однос између вредносних оријентација које су део културе (попут индивидуализма и колективизма) и упадљиве потрошње. Налази су умногоме контрадикторни и за саме истраживаче јер је уочљива поплава луксузне потрошње управо у источноазијским земљама у којима доминира колективистичка култура (Wong, 1997).

Истраживачи са универзитета у Бону указали су на то да упадљива потрошња може бити облик снобизма, али и конформизма са друге стране. Они су истраживали понашање потрошача које има за 
циљ да прикаже високе личне приходе и тако повећа друштвени статус. Када је модел у равнотежи, сигнална вредност упадљиве потрошње зависи од броја потрошача. Попут еквилибријума у теорији игара, потрошачке одлуке могу бити усмерене на супротстављање или саучествовање. Тако је у зависности од особина личности потрошача, његовог релативног положаја у друштву и сигналне вредности потрошње адекватна стратегија снобизам или конформизам (Corneo \& Jeanne, 1997).

У низу независних истраживања на нашем културном и језичком поднебљу емпиријски смо утврдили да је феномен упадљиве потрошње присутан и код богатих и код сиромашних потрошача, и код старијих и млађих испитаника, као и његову повезаност са различитим конструктима. Међу конструктима који су значајни показатељи позитивног односа према упадљивој потрошњи су: конформизам (Velov, Bosiok, Mitić i Đurić, 2010), власт као интерперсонална вредност (Mitić, Velov i Đurić, 2010; Vukićević, Velov, Mitić i Đurić, 2011), димензије ауторитарне структуре личности, социјална анксиозност (Vukićević, Mitić i Đurić, 2012), макијавелизам (Mitić, Vukićević i Đurić, 2011), нарцизам (Vasić, Vujović i Stamenković, 2012; Roksić i Mitić, 2012).

\section{ТЕОРИЈСКИ И КОНТЕКСТУАЛНИ ОКВИР}

Упадљива потрошња (енгл. conspicuous consumptin) и упаљива доколица (енгл. conspicuous leisure) јесу централни појмови Вебленовог (Thorstein Veblen) дела Теорија доколичарске класе из 1904. године, које представља његов одговор на забринутост јавности због америчке индустријализације и друштвене стратификације тог доба. Веблен уопштава сукобе настале друштвеним раслојавањем рекавши да су сукоби постојећих и новонасталих норми последица урођене човекове склоности да манипулише и учи од референтне групе (Veblen, 2008).

За развој социјалне компетиције изузетно је важна трансформација основних принципа сексуалне селекције у широку лепезу различитих облика сигналне селекције (Johnstone, 1997). Интерсексуална сигнализација код животиња представља развијену репродуктивну стратегију привлачења пажње потенцијалних сексуалних партнера. Класичан пример интерсексуалне сигнализације је паунов реп, којим се мужјаци такмиче да буду бирани од стране женки. Иако је незграпан реп велики терет и представља ризик за опстанак, њиме се демонстрира симетрија тела, а посредно и квалитет гена (Luxen \& Buunk, 2006). Веблен је сматрао да се овај природни „инстинкт" код људи трансформисао (еволуирао) у својеврсну врсту конзумеризма - у упадљиву потрошғу. Људи, били они богати или 
сиромашни, теже да импресионирају друге материјалним престижом и убиру користи упадљивог благостања и доколице. Према Веблену, потрошња је средство које нам омогућава да сигнализирамо свој друштвени статус (Veblen, 2008). Имитација игра важну улогу у овој динамици и одређује сексуалне преференције - и код животиња и код људи. Још неки примери скупог сигнализирања код људи су преузимање ризика, лов, учешће у појединим религиозним ритуалима (Fisher, 1915). Као и у класичној теорији сигналне селекције, ови сигнали могу бити искрени модели еволутивно стабилних стратегиja, али свакако постоје и неискрени сигнали, као и обмане. Ти „лажни сигнали”, игре варки и „блефирања” директна су последица интеракције заједничких циљева и супротстављених интереса јединке. Дакле, у основи пропорције између искрених и неискрених репродуктивних сигнала је сукоб алтруистичне (колективне) и индивидуалне добити (Johnstone, 2002).

Економско понашање и развијено потрошачко друштво донели су нове и сложеније механизме социјалне компетиције. Анализирајући живот владајуће класе, Торстен Веблен је покушао да објасни изворе ирационалних естетских феномена и употребе времена за доколицу. Морал, укус, естетски принципи, навике и цео живот друштва одређени су „новчаним канонима укуса”, а јефтино одело чини човека јефтиним (Veblen, 2008). Доколичарска класа се стога окружује производима који су незграпни, неретко бескорисни, али скупи. Грађанска класа постепено ствара одвратност према свему што је корисно и усваја културу која захтева максимум непроизводних напора, изражавајући тако супериорност. Корисна средства за стицање угледа су рогобатна, архаична и, из друштвеног угла, бескорисна. Она постоје да би изразила „ослобођеност од привређивања”. Основне социјалне категорије Вебленове теорије јесу „новчано такмичење”, „упадљиво ленствовање” и „упадљива потрошња”. Економско такмичење има улогу покретачке силе друштвеног развитка, изазива завист која даље подстиче упадљиво расипништво. Мотив је емулација (аналогно животињским инстинктима) - стимулус непријатног поређења, које нас наводи да надмашимо оне са којима смо навикли да се поредимо.

Људи данас живе у „хиперреалности” симулација у којој слике, одрази и игра знакова замењују концепте производње и класне борбе као кључни конституенти савременог друштва. У друштву симулакрума и симулација идентитети су конструисани присвајањем знакова, а кодови и модели одређују начин на који појединци виде сами себе и односе се према другима (Bodrijar, 1991). Језгро Вебленових идеја и дарвинистички принципи се у модерним теоријама потрошачког понашања и те како користе. Најновија истраживања усмерена су на давање објашњења о томе како маркетинг експлоати- 
ше наше наслеђене инстинкте да прикаже социјални статус као репродуктивну предност. Џефри Милер (Geoffrey Miller), водећи еволуциони психолог данашњице, тврди да модерна култура у којој доминантни маркетинг ствара потрошачке изборе и навике представља аберацију генетског наслеђа старог два милиона година. У малим групама, у каквим је човек навикао да живи, социјални статус био је основни покретач репродукције. Милерова теза јесте да маркетинг убеђује људе, посебно младе, да је најефикаснији начин приказивања статуса кроз потрошачке одлуке. Много је теже, мање експлицитно, редундантно је и захтева више времена истицање интелигенције и особина личности кроз интерпретативна средства комуникације, као што је разговор (Miller, 2009). Данас је потрошња значајно средство комуницирања. Ми саопштавамо своје ставове и изражавамо своју личност кроз производе које купујемо. Млади саопштавају да припадају одређеној супкултури или јој се пак супротстављају ношењем одређених модних марки, истицањем симбола референтних група и коришћењем различитих престижних техничких уређаја. У зависности од тога у шта су спремни да улажу своје ресурсе, истичу различите еволутивно пожељне карактеристике: ментално здравље, физичко здравље, атрактивност, тенденцију дугог живота, вероватноћу успешне репродукције. Дакле, Милер проширује концепт упадљиве потрошње на улагање материјалних ресурса у истицање животног стила, који не мора бити „доколичарски”, али има улогу еволутивно развијеног облика сигнализације. Она нам помаже не само да одаберемо адекватне сексуалне партнере већ и да стварамо продуктивне друштвене коалиције.

Коначно, свеприсутне друштвене мреже постају још један медиј за истицање потрошње и поткрепљују парадигму „постмодерног", хиперреалног, сигналног света. У овом виртуелном свету појединци сигнализирају свој животни стил и статус одабирањем и објављивањем омиљених модних брендова, ресторана, клубова, туристичких дестинација или пак објављивањем припадности одређеним групама. Ту су представљања нашминканих фотографија са ексклузивних дестинација и догађаја, фотографија у друштву утицајних људи, у друштву вредних „коалиционих партнера”, у друштву атрактивних сексуалних партнера, фотографије и активности које истичу добар укус, интелект, духовитост, статус, здравље, безбрижност, друштвену одговорност. Ту је готово све оно што улази у традиционално генетско ценкање, лепо и суптилно упаковано у пакетиће мема.

Тако од компетиције бољих гена долазимо до компетиције трансформисаних сигнала. А шта је у основи тих сигнала и како се они конструишу и трансформишу? Несумњиво је да усвајају елементе престижа из референтне културе, о чему говоре међукултуралне разлике, али исто тако и да постоје универзални меми за ове сигнале. 
Када говоримо о упадљивој потрошњи, говоримо о једном манифестном облику испољавања мема карактеристичном за савремене, потрошачки оријентисане културе. Оваква манифестација мема омогућава њихово емпиријско изучавање. Можемо истраживати интерпретативна и денотативна значења луксузних производа, као и њихову релативну вредност и функције у одређеној култури. Поред тога, можемо истраживати конативне изворе потрошачког понашања и доводити их у везу са животним стиловима, интерперсоналним вредностима, стратегијама социјалне компетиције и слично. Коначно, међукултурална истраживања потрошње (посебно упадљиве потрошње) пружају нам емпиријска знања о варијацијама и мутацијама одабраних мема.

Мода је само један од транспарентних кодова културе. Истраживачи културе који се баве модом, међукултуралним разликама, њеним развојем кроз историју говоре о културним кодовима моде. Ови кодови садржани су у избору материјала, боје, текстуре, форме, транспарентности, волумена и слично. У зависности од њихове комбинације, формира се низ димензија као што су: младост-старост, маскулиност-фемининост, андрогинија-сингуларност, инклузивност-ексклузивност, рад-забава, домаће-светско, откривено-прикривено, слободно-уздржано и конформизам-бунт (Davis, 1994). Нормално у односу на ове димензије постављена је димензија статуса која кодове моде доводи у један хијерархијски неравноправан положај. Данас је ова димензија све чешће повезана са одабиром модних марки или дизајнера. Историјски посматрано, она је одувек постојала и представљала чврсту границу социјалног статуса, припадности одређеном сталежу или класи. Промене које се дешавају у моди од средњовековне Европе до данас не говоре само о разликама у стилу и укусу већ говоре о томе да је одећа одувек играла значајну улогу у комуникацији, компетицији и стварању културног идентитета (Breward, 1995).

Зашто смо овде издвојили пример моде, а не архитектуре, уметности или, рецимо, религије? Неколико је разлога. Мода одевања је карактеристичан и универзалан пример социјалног (вертикалног и хоризонталног) раслојавања, независно од културе из које потиче. Она експлицитно илуструје упадљиву потрошњу. Учествује у статусној и сексуалној компетицији посредством сигналног система. Овај сигнални систем сачињен је од културних информација - мема. Доступна је свима. Посредује у стварању и пројекцији личног идентитета. Посредује у стварању и представљању социјалног идентитета. Подлеже имитацији. Врло је динамична у својим променама.

Динамика утицаја модерног, хиперреалног света нарочито је видљива код супкултуре младих (Sherif \& Sherif, 2008). У вршњачким адолесцентним групама формирају се модели и стандарди о пожељним карактеристикама особа, начину коришћења слободног вре- 
мена, економском понашању. У овим групама се стварају примарне коалиционе скупине и неформално се формирају хијерархије вођства и моћи. У школским клупама најпре се дефинишу стилови компетиције, правила компетитивног понашања и удруживања. Поред тога је присутнији конформизам и антиконформизам у односу на норме одраслих. Једна од значајних норми којима се адолесценти приклањају управо је норма у вези са одевањем и изгледом, на основу које се регулише групна хијерархија, мушка и женска, издвајају ауторитети и формирају подгрупе.

\section{МЕТОДОЛОГИЈА И ХИПОТЕЗЕ ИСТРАЖИВАЬА}

Неекспериментално испитивање било је анкетног типа и спроведено је на узорку од 200 испитаника - ученика завршних разреда средњих школа у Нишу и Новом Саду током априла и маја 2015. године. Истраживањем су обухваћене следеће школе из Ниша: Прва нишка гимназија „Стеван Сремац”, Гимназија „Бора Станковић”, Грађевинско-техничка школа „Неимар” и Административнобиротехничка школа. У Новом Саду је испитивање извршено у две школе: у Гимназији „Светозар Марковић” и Средњој машинској школи Нови Сад. Узорак испитаника је полно уједначен $(53,5 \%$ мушког и 46,5\% женског пола).

Упитник који је коришћен за прикупљање података садржи скалу става према упадљивој потрошњи АТCC (Mitić, Velov, Đurić, 2010). Скала садржи 55 ставки. Сачињена је у виду петостепене скале Ликертовог типа, при чему број 1 означава потпуно неслагање, а 5 потпуну сагласност са задатом тврдњом. Све ставке изражавају став према куповини и ношењу фирмиране одеће. Тврдње су формулисане у трећем лицу или као општи ставови, чиме је превентивно смањено присуство социјално пожељних одговора. Психометријске карактеристике ове скале испитане су на узорку од 833 средњошколца из 15 средњих школа и гимназија са територије Новог Сада, Београда и Ниша (Kosanović, Vukićević i Đurić, 2011), при чему су показатељи поузданости указали на то да се ради о инструменту са одличним психометријским карактеристикама.

Експериментални део истраживања спроведен је на узорку студената прве године различитих студијских усмерења са Факултета за правне и пословне студије др Лазар Вркатић у Новом Саду. Шездесет испитаника је произвољно подељено на две групе, а задатак им је био да на седмостепеној скали процене одабране карактеристике особе коју виде на фотографији. Обе групе су процењивале по петнаест карактеристика истих особа, само што је једна група добила фотографије на којој је дигитално измењена мајица коју особа носи. На мајице је дигитално „прилепљен” логотип бренда који мла- 
ди увиђају као луксузан (скуп), што су у овом случају били: Лакоста (Lacoste), Ралф Лорен (Ralph Lauren) или Томи Хилфигер (Toтmу Hilfiger). Ради контроле, обе групе су процењивале и неколико неутралних фотографија. Другим речима, једини стимулус који смо варирали код експерименталне и неекспериенталне групе јесте присуство логотипа на одабраним фотографијама. Контрола је обезбеђена употребом неутралних фотографија и расподелом испитаника у блокове. Испитаници су процењивали на седмостепеној скали колико је особа коју виде на фотографији: 1) привлачна, 2) лепа, 3) занимљива, 4) искрена, 5) поштована, 6) дружељубива, 7) популарна, 8) богата, 9) образована, 10) самоуверена, 11) способна, 12) моћна, 13) успешна, 14) паметна и 15) поуздана. Претпоставили смо да ће фотографије на којима је присутан стимулус (логотип бренда) бити статистички значајно боље оцењене (имати статистички значајно више просечне резултате). Очекивали смо да позитивно виђење статуса „боље обучене” особе повлачи са собом и позитивнију перцепцију других карактеристика, као што су привлачност или образовање.

Сви резултати анализирани су употребом статистичког програма IBM SPSS Statistics 19. После кодирања и уноса у матрицу, подаци су анализирани применом стандардних поступака статистичке дескрипције, статистике закључивања и мултиваријатне анализе индивидуалних разлика. Применом експлоративне факторске анализе испитали смо латентну димензионалност конструкта. За процену разлика користили смо стандардни Студентов т-тест за независне узорке. У статистичком закључивању прихватили смо ниво значајности од $\alpha=0,05$.

\section{РЕЗУЛТАТИ И ДИСКУСИЈА}

Скала става према упадљивој потрошњи је, као и у претходним истраживањима, показала изузетно висок ниво интерне конзистенције вредности $(\alpha=0,93, \mathrm{~m}=55)$. Њена факторска структура је смислена и интерпретабилна, премда редослед и структура екстрахованих фактора нису у потпуности реплицирани. У готово свим претходним истраживањима међу главним компонентама издвајале су се „Привлачност”, „Престиж” и „Поштовање”, као и у овом случају.

Наши испитаници су „препознали” употребу фирмираних производа као средство којим се повећава интерперсонална привлачност, истичу позитивни атрибути особе која је поседује и привлачи пажња, што је дефинисано првим екстрахованим фактором. Садржај друге факторске компоненте дефинисан је ставом да је ношење фирмиране одеће симболично приказивање материјалног статуса, богатства, престижа, луксуза, успеха. Трећа компонента описује фирмирану одећу као тактику интерсексуалног и интрасексуалног надметања међу вршњацима. 
Куповина и ношење фирмиране одеће имају за циљ да истакну друштвено пожељне атрибуте особе, попут доброг материјалног статуса, успеха, моћи и популарности међу вршњацима. Дакле, овај облик понашања може адекватно представити домен конструкта упадљиве потрошње, са свим њеним основним карактеристикама, на које је и Торстен Веблен (Veblen, 1904/2008) давно указао. Упадљива потрошња јесте елемент симболичке размене и моћно средство невербалне комуникације данашњице. Иако се одупиремо признању да доносимо закључке о људима на основу одеће коју носе, верујемо да већина људи то ипак ради. Због тога је, при мерењу овог конструкта, важно уочити тенденцију порицања личних материјалистичких ставова и приступити му посредно, кроз опште тврдње. Овде је то постигнуто специфичном формулацијом стабла ставки. Ипак, не можемо да се не запитамо зашто је тако социјално непожељно признати да се служимо упадљивом потрошњом како бисмо промовисали себе. На питање да ли други људи носе фирмирану одећу да би истакли свој статус, 97\% испитаника одговара потврдно. Са друге стране, на питање „Да ли Ви носите фирмирану одећу да бисте истакли сопствени статус?", највећи број испитаника одговара негативно!

Нисмо установили статистички значајне разлике повезане са полом испитаника $\left(F_{(1,198)}=1,75 ; p=0,22\right)$. Истраживања о одабиру партнера указују на то да се од мушкараца више очекује да отворено прикажу поседовање луксузних ресурса. На пример, жене сматрају да је поседовање материјалних ресурса за мушкарца нужност, а мушкарци исто код жена перципирају као луксуз (Griskevicius et al., 2007). У истом истраживању закључено је да су особе женског пола мање агресивне и просоцијално оријентисане јер се код њих беспомоћност не посматра као одраз еволутивне слабости. Са друге стране, мушкарци су компетитивнији зато што се то од њих очекује и зато што је у складу са њиховом полном улогом. Зашто у овом раду то није случај? Ово истраживање је спроведено на узорку младих људи, просечне старости између 17 и 18 година. Иако су они достигли полну зрелост, њихове репродуктивне стратегије још увек нису усмерене на приказивање могућности улагања у потомство. Они углавном нису материјално независни, нити усмерени на дугорочно везивање са партнерима супротног пола. Стога, упадљива потрошња у овом контексту не мора да имплицира полне разлике, али и даље може представљати средство интрасексуалног надметања. Чак и када је реч о стратегијама тражења краткорочних партнера, упадљива потрошња је важно сигнално средство. Она у овом случају саопштава спремност особе да се препусти разоноди и да више улаже у забаву, путовања и доколицу, да безбрижније пролази кроз животне препреке (Sundie et al., 2011). Код младих то значи више слободе и могућност да се стекне више искустава. Млади који носе фирмирану оде- 
ћу, користе скупу мобилну технологију и уређаје саопштавају вршњацима да имају више аутономије у одлучивању, да имају више слободе у антиконформирању одраслима, да могу себи и другима приуштити бољу забаву и несвакидашња искуства.

Нисмо установили статистички значајне разлике повезане са материјалним статусом испитаника $\left(F_{(1,198)}=1,13 ; p=0,29\right)$. Ово је такође занимљив налаз, али није изненађење. Истраживања упадљиве потрошње на глобалном нивоу указују на то да је ово универзални феномен, независан од материјалног статуса појединца. Перцепција и високо вредновање луксузних производа део су универзалне симболичке комуникације. Људи који носе скупу фирмирану одећу биће перципирани као успешнији и привлачнији, независно од статуса посматрача (онога ко оцењује).

Управо овај став је потврђен спроведеним експериментом. Нас је интересовало да ли и како логотипи скупих брендова на одећи утичу на перцепцију особе која је носи. Резултати су потврдили постојање статистички значајних разлика на тринаест од петнаест одабраних карактеристика: Привлачност без логотипа $(\mathrm{M} 1=4,17$, СД1 $=1,72)$ и Привлачност са логотипом $(\mathrm{M} 2=6,03, \mathrm{CД} 2=1,42), t_{(58)}=$ 4,57, $<$ < 0,01; затим Лепота (M1 = 4,43, СД1 = 1,85; М2 =6,13, СД2 $=1,2), t_{(58)}=4,23, \mathrm{p}<0,01 ;$ Дружељубивост $t=3,74, \mathrm{p}<0,01 ;$ Искреност $t=3,13, \mathrm{p}<0,01 ;$ Успех $t=3,27, \mathrm{p}=0,02 ;$ Поштоване $t=3,74, \mathrm{p}$ $=0,01 ;$ Занимљивост (колико је особа занимљива) $t=2,9, \mathrm{p}<0,01$; Популарност $t=4,58, \mathrm{p}<0,01 ;$ Богатство $t=2,38, \mathrm{p}=0,02 ;$ Образовање $t=2,62, \mathrm{p}<0,01 ;$ Самоувереност $t=4,11, \mathrm{p}<0,01$; Способност $t=2,07, \mathrm{p}=0,04 ;$ Moћ $t=3,34, \mathrm{p}<0,01$. Карактеристике код којих разлике нису биле статистички значајне су Памет и Поузданост. Контролне фотографије које су биле исте за обе групе очекивано нису показале статистички значајне разлике између група.

Очекивали смо да позитивно перципирање статуса „боље обучене" особе повлачи са собом и позитивнију перцепцију других карактеристика, као што су привлачност или образовање. Међутим, у овом експерименту смо варирали само детаљ на мајицама (истакнут бренд или небрендирана мајица), што застрашујуће говори у прилог снази овог вида симболичке комуникације. Стимулус попут мајушног логотипа на мајици снагом хало-ефекта уопштава утисак о особи коју не познајемо приписујући јој позитивне карактеристике. У овом случају смо испитали само три бренда као извор стимулуса, па стога нисмо били у могућности да испитамо разлике између валенци самих брендова. Верујемо да би неко наредно истраживање могло да утврди и овај ниво разлика.

Занимљиво је анализирати зашто се стимулус није показао као значајан извор разлика на карактеристикама Памет и Поузданост. Нажалост, подаци које имамо остављају нам само простор за спеку- 
лативне закључке. Међутим, не можемо а да се не запитамо да ли су интелигенција и поштење остали запостављени у игри савремене социјалне компетиције која се игра посредством луксузне симболичке размене.

\section{ЗАКЉУЧАК}

Упадљива потрошња је универзалан феномен и као такав представља значајно средство комуникације међу људима. Истраживање је показало да млади у Новом Саду и Нишу користе овај облик комуникације као значајан извор информација и формирају примарни утисак о особи на основу интегрисаних симболичких кодова који су део упадљиве потрошње. Врло често на несвесном (инстинктивном) нивоу реагујемо на статусне симболичке кодове, што може проузроковати хало-ефекат у социјалној перцепцији.

Млади користе фирмирану одећу и престижну информациону технологију како би вршњацима саопштили свој статус, позиционирали се у друштву, поредили, такмичили, били прихваћени и да би привукли пријатеље или емотивне партнере. Са друге стране, они су свесни да је њихов комуникацијски код перципиран и важан. Ипак, нико не признаје радо да користи упадљиву потрошњу, јер је ово знак слабости, мимикрије, обмане и слично.

Упадљива потрошња налази своје место како у социолошким и антрополошким теоријама тако и у еволуционим и социобиолошким теоријама. Стога не смемо донети вредносни суд када говоримо о овом облику понашања. Чини се да је људска потреба за истицањем адаптивних вредности у репродуктивне сврхе (паунов реп) еволуирала у савремене видове комуникације и једним делом заменила традиционалне биолошке информативне кодове културним.

\section{ЛИТЕРАТУРА}

Bordijar, Ž. (1991) Simbolička razmena i smrt [Symbolic Exchange and Death]. Gornji Milanovac: Dečje novine.

Breward, C. (1995) The Culture of Fashion. Manchester: Manchester University Press.

Corneo, G. \& Jeanne, O. (1997) Conspicuous consumption, snobbism and conformism. Journal of Public Economics, 66, (1), 55-71

Dawis, F. (1994) Fashion, Culture, and Identity. Chicago: University of Chicago Press.

Fisher, R. A. (1915) The evolution of sexual preference, Eugenics Review, 7, 184-192.

Griskevicius, V., Tybur, J. M., Sundie, J. M. , Cialdini, R. B. , Miller, G. F., Kenrick, D. T. (2007) Blatant Benevolence and Conspicuous Consumption: When Romantic Motives Elicit Strategic Costly Signals, Journal of Personality and Social, 93, (1), 85-102.

Johnstone, R. A. (1997) The evolution of animal signals. Behavioural ecology: an evolutionary approach. Blackwell, Oxford, 4, 155-178. 
Johnstone, R. A. (2002) Signalling of need, sibling competition, and the cost of signaling. Proc. Nat'l. Acad. Sci. USA, 96, 12644-12649.

Kosanović, B., Vukičević, L., Đurić, V. (2011) Metrijske karakteristike i faktorska struktura skale za ispitivanja odnosa prema upadljivoj potrošnji [Metric Characteristics and Factor Structure for Attitude toward Conspicuous Consumption Scale]. Civitas, 2, 24-33.

Luxen, M. F., and Buunk, B. P. (2006) Human Intelligence, fluctuating asymmetry and the peacock's tail: General Intelligence (g) as an honest signal of fitness, Personality \& Individual Differencces, 41,(5), 897-902.

Miller, G. F. (2009) Spent: Sex, Evolution, and Consumer Behavior. New York: Viking Adult.

Mitić, A., Velov, B., Đurić, V. (2010) Stav prema upadljivoj potrošnji i interpersonalne vrednosti kod mladih [Attitude toward Conspicuous Consumption and Interpersonal Values of Young People]. Zbornik radova sa Međunarodnog naučnog skupa „Društveni izazovi evropskih integracija - Srbija i uporedna iskustva”, 105-113. Novi Sad: USEE.

Mitić, A., Vukičević, L., Đurić, V. (2012) Makijavelizam i stilovi socijalne kompeticije kao prediktori stava prema upadljivoj potrošnji [Machiavellianism and Social Competition Styles as Predictors of Attitudes toward Conspicuous Consumption]. 18. naučni skup Empirijska istraživanja u psihologiji, 118-119.

Roksić, T., Mitić, A. (2012) Životni stil i odnos prema upadljivoj potrošnji kod nosilaca različitih životnih stilova [Lifestyle and Attitude toward Conspicuous Consumption]. 18. naučni skup Empirijska istraživanja u psihologiji, 123-124.

Sherif, M. \& Sherif, W. C. (2008) Problems of Youth: Transition to Adulthood in a Changing World, New Jersey: Transaction Publishers.

Sundie, M. J., Griskevicius, V., Vohs, K. D., Kenrick, D. T., Tybur, J. M., Beal, D. J. (2011) Peacocks, Porsches, and Thorstein Veblen: Conspicuous Consumption as a Sexual Signaling System, Journal of Personality and Social Psychology $100,(4), 664-680$.

Vasić, J., Vujović, M., Stamenković, S. (2012) Upadljiva potrošnja i narcizam [Conspicuous Consumption and Narcissism]. 18. naučni skup Empirijska istraživanja u psihologiji, 120-121.

Veblen, T. (2008) Teorija dokoličarske klase [Theory of the Leisure Class]. Novi Sad: Mediterran Publishing.

Velov, B., Bosiok, D., Mitić, A., Đurić, V. (2010) Upadljiva potrošnja, osetljivost na interpersonalni uticaj i konformizam kod mladih [Conspicuous Consumption, Sensitivity to Interpersonal Influence and Conformity among Youth], XVI naučni skup Empirijska istraživanja u psihologiji, 80-81.

Vukičević, L., Velov, B., Mitić, A., Đurić, V. (2011) Psihološki korelati pozitivnog stava prema upadljivoj potrošnji [Psychological Correlates of Positive Attitudes toward Conspicuous Consumption]. Knjiga rezimea: XVII naučni skup Empirijska istraživanja u psihologiji, 143-144.

Vukičević, L., Mitić, A., Đurić, V. (2012) Socijalna anksioznost i odnos prema firmiranoj garderobi kod učenika šestog i sedmog razreda osnovne škole [Social Anxiety and Attitude towards Branded Clothes among Pupils of the Sixth and Seventh Elementary School Grades]. 18. naučni skup Empirijska istraživanja u psihologiji, 118-119.

Wong, N. Y. C. (1997) Suppose you own the world and no one knows? Consicuous consumption, materialism and self, Advances in Consumer Research, Association for Consumer Research, 24, 197-203. 


\title{
ROLE OF CONSPICUOUS CONSUMPTION IN SOCIAL INTERACTION AND PERCEPTION
}

\author{
Anja Mitić ${ }^{*}$, Ivana Petrović ${ }^{2}$, Veljko Đurić ${ }^{3}$ \\ ${ }^{1}$ University of Belgrade, Faculty of Philosophy, Belgrade, Serbia \\ ${ }^{2}$ Faculty for Legal and Work Studies Dr. Lazar Vrkatić, Novi Sad, Serbia
}

\begin{abstract}
Summary
Conspicuous consumption is usually defined as purchase and accumulation of luxury products with the intention to point out an enviable social status. Shopping and accumulation of luxury products has a semantic potential and through integrated cultural codes participates in the symbolic exchange between individuals and groups. On the other hand, there are evolutionary sources of tendencies towards this form of symbolic social competition. Whether we like it or not, the clothes we wear affect how others perceive us. Even the details like the logo of a prestigious brand on a shirt can contribute that others perceive us as more successful, more competent and attractive. Although the scientific community has not been engaged in conspicuous consumption for a long time, this has become a very attractive topic nowadays. Conspicuous consumption is so marked by the behavior of the Western culture and determines its class boundaries, that it became the core of the economic, cultural, sociological and psychological debates today.

The subject of the paper is to examine the effects of conspicuous consumption on the perceptions and attitudes of young people in Serbia. This paper presents the results of the experimental empirical research, aimed to investigate the role of this phenomenon in social interaction and the perception of young people. The experiment was preceded by extensive non-experimental study with the purpose to investigate the affection of the youth toward luxury goods, especially clothes. The non-experimental survey was conducted on the sample of 200 respondents - final high school year students from Niš and Novi Sad. The analysis of the results shows that buying and wearing branded clothes is intended to highlight socially desirable attributes of a person, like a good financial situation, success, power, and popularity among peers. There were no statistically significant differences related to gender, financial status or the origin of the respondents.

The experiment tested whether and how logos of expensive brands on the clothes affect the perception of the person who wears it. Sixty respondents were randomized into two groups, and their task was to assess the seven-level scale about selected characteristics of the person they saw in the photo. Both groups evaluated fifteen characteristics of the same person, but one group was given digitally altered photographs. Brand logos that young people perceive as luxurious have been digitally "glued" onto the experimental shirts. The results confirmed the existence of statistically significant differences in thirteen of the fifteen selected features. We expected that positive perception of the status of the "better trained" people entails a more positive perception of other characteristics, such as attraction or education. However, in this experiment, we varied only a detail on T-shirts (enhanced brand or unbranded shirt), which speaks in favor of the frightening power of this form of symbolic communication. The purpose of this paper is to indicate the presence and role of conspicuous consumption in the contemporary context, as well as showing its impact in social interaction and the perception among young people in Serbia.
\end{abstract}

